\title{
Bukan Salib Biasa: Menelusuri Pemahaman Berdasarkan Biblical
}

\author{
Arif Yupiter Gulo ${ }^{1}$ \\ Sekola Tinggi Teologi Pokok Anggur Jakarta
}

glyupiarif@gmail.com

\section{Pendahuluan}

The Christian cross is regarded as the primary symbol of the Christian religion. ${ }^{2}$ Itu sebabnya, ada sebagian masyarakat kristen mengenakan salib, baik di gedung gereja, maupun dikenakan sebagai kalung. Bahkan, di taman makam pun salib dipasang untuk menandakan sebagai kuburan orang yang beragama nasrani. Persoalan yang menjadi perhatian yang sangat serius belakangan ini, bahwa salib dirobohkan di tempat-tempat umum dan dijadikan sebagai bahan lelucun dan tertawaan sehinggga menyinggung perasaan orang kristen. Dalam berita Yogya diberitakan melalui wawancara dengan pengurus makam mengatakan, ada delapan nisan salib yang dicabut dari pusaranya dan tergeletak ditanah, bahkan beberapa yang sudah dibakar. ${ }^{3}$ Selain itu, dalam berita nasional tempo memberitakan bahwa:

Ketika sekelompok masyarakat meminta keluarga memotong simbol salib pada nisan Albertus Slamet Sugiardi, seorang penganut Katolik, di Permakaman Jambon, RT 53 RW 13 Kelurahan Purbayan, Kotagede, Yogyakarta. Mereka tak ingin tanda agama Katolik ada di area permakaman. Mereka berdalih ingin menjadikan kompleks tersebut sebagai area permakaman khusus muslim. Mereka juga meminta makam Slamet dibuat di pinggir permakaman. Nisan Slamet pun tinggal berbentuk huruf T. Setelah permakaman, warga setempat melarang keluarga untuk menggelar doa arwah. Ketua RT 53, Soleh Rahmad Hidayat, berdalih tak adanya simbol kristiani di makam telah menjadi aturan tak tertulis warganya. Warga pun

\footnotetext{
${ }^{1}$ Dosen Teologi Biblical, Perjanjian Baru dan Sosiologi Agama di STT Pokok Anggur Jakarta dan juga sebagai Pendeta di Banua Niha Keriso Protestan (BNKP)

${ }^{2}$ Artikel yang dikutip tanggal 20 Agustus 2019 di https://www.worldatlas.com/articles/thehistory-of-the-christian-cross.html

${ }^{3}$ Artikel ini dikuip tanggal 20 Agustus 2019 di https://jogja.suara.com/read/2019/04/06/221120/nisan-salib-di-yogyakarta-dibakar-terduga-pelakusempat-tidur-di-makam
} 
meminta Maria Sutris Winarni untuk menandatangani surat pernyataan yang berisi keikhlasan untuk menghilangkan tanda salib tersebut. ${ }^{4}$

Bahkan baru-baru ini sangat viral di Medsos terkait dengan video pendek dari salah seorang ulama yang terkenal yaitu UAS (Ustad Abdul Somad) yang sangat kontroversi. Dalam salah satu ceramah yang kemudian diunggah ke internet, pak Somad ditanya soal salib. Dia menjawab pertanyaan seorang hadirin tentang mengapa ketika melihat salib, hatinya menggigil. Pak Somad berusaha menjawab secara lucu. Dia mengatakan bahwa di dalam salib itu ada patung. Hadirin tertawa ketika dia berusaha memperagakan patung itu. ${ }^{5}$ Sambil memperagakan patung itu, pak Somad bertanya (patung itu) hadap ke kiri atau ke kanan. Tidak ada yang tahu. Hadirin tertawa lagi. Kali ini lebih keras. Pak Somad memberikan jawaban mengapa salib membuat hati pemirsanya menggigil: karena ada jin kafir pada patung di salib itu. ${ }^{6}$ Berdasarkan pernyataan UAS tersebut menuai banyak komentar dan pendapat yang seragam yang menekankan bahwa pernyataan tersebut menghina dan menista agama nasrani sebab salib merupakan lambang atau simbol agama Kristen. Oleh karena itu, kelompok organisasi tertentu menempuh jalur hukum sehingga melaporkan UAS di POLDA NTT dan juga di Jawa Timur agar ditangani dan diberikan sangsi sesuai hukum yang berlaku. Berdasarkan hal itu, maka penulis akan menguraikan pemahaman tentang salib secara komprehensif dan eksplisit guna untuk memberikan kontribusi bagi orang Kristen maupun bagi non Kristen. Dalam menguraikan pemahaman tentang salib ini, penulis menjelaskan tentang latar belakang salib, salib menurut Perjanjian Lama dan Perjanjian Baru serta penjelasan Yesus tentang salib yang menimpa diri-Nya. Bahkan yang tidak kalah penting adalah implikasi teologis dalam memaknai salib bagi iman kekristenan.

\section{Metodologi}

Metode yang dipakai oleh penulis dalam tulisan ini adalah metode peneltian kualitatif. Kata Kulitatif sendiri menyiratkan penekanan pada proses dan makna

${ }^{4}$ https://nasional.tempo.co/read/1157220/pemotongan-tanda-salib-dianggap-indikasikanpelemahan-toleransi/full\&view=ok diakses Tanggal 20 Agustus 2019

5 Artikel di kutip tanggal 20 Agustus 2019 di https://indoprogress.com/2019/08/salib-jinkafir-dan-papua/

${ }^{6}$ https://indoprogress.com/2019/08/salib-jin-kafir-dan-papua/ Ibid, tanggal 20 Agustus 2019 
yang tidak secara ketat diperiksa atau diukur dari segi jumlah, intensitas, dan frenkuensinya, tetapi menekankan sifat realitas yang disusun secara social, hubungan antara peneliti dan yang diteliti, dan pembatasan situasional yang membentuk penelitian. ${ }^{7}$ Yakob Tomatala mengatakan bahwa, metode penelitian kualitatif adalah pendekatan analisa dengan penalaran induktif menggunakan teknik analisa untuk memahami suatu masalah secara subjektif. Tujuan dari metodologi ini ialah untuk menemukan hipotesis menghasilkan suatu teori baru. Teori baru tersebut adalah pengembangan dari teori yang ada (koresponden/koheren) yang merupakan konklusi (proposisi) yang berlaku umum. ${ }^{8}$ Sedangkan Biblical yang dimaksud adalah melakukan kajian berdasarkan Alkitab guna menjawab kontroversi yang berkembang tentang Salib. Andreas B Subagyo mengatakan, Kajian Alkitab berupaya menyelidiki Alkitab dan bagian-bagiannya sebagai teks. ${ }^{9}$ Teks dalam arti yang lebih khusus yang mengacu pada kaitannya dengan ayat-ayat Alkitab yang berkaitan dengan salib.

\section{Latar Belakang Salib.}

Sebelum kekristenan, menurut artikel Worldatlas mengungkapkan, A vast body of evidence shows that the cross was used centuries before the birth of Christianity. The cross is thought to have originated from the ancient Babylonians before its spread to other parts of the world such as Syria, Egypt, Greek, Latin, India, and Mexico. ${ }^{10}$ Kemudian dipertegas lagi bahwa "sebelum kekristenan digunakan sebagai simbol agama dan sebagai ornament diantara Mesir, Siria, Yunani, eropa dan beberapa bagian Afrika. ${ }^{11}$ Selain itu, The use of the Christian

${ }^{7}$ Andreas B. Subagyo, Ph.D. Pengantar Riset Kuantitatif dan Kualitatif, Bandung: Yayasan Kalam Hidup, 2014, hal 62.

${ }^{8}$ Yakob Tomatala, Metodologi Riset Pendekatan Penelitian Kuantitatif dan kualitatif, Jakarta: YT Leadership Foundation, 2014,hal 26

${ }^{9}$ Andreas B Subagyo, Pengantar Riset Kuantitatif dan Kualitatif, hal 125

${ }^{10}$ artikelhttps://www.worldatlas.com/articles/the-history-of-the-christian-cross.html diakses tanggal 27 Agustus 2019

${ }^{11}$ artikelhttps://www.worldatlas.com/articles/the-history-of-the-christian-cross.html Ibid, diakses tanggal 27 Agustus 2019 
cross as a Christian symbol began after the time of the Constantine, which occurred three centuries after the coming of Christ. ${ }^{12}$

Pada sisi lain Andreas Yewangu mengatakan,

Apa itu salib? Tidak lain dari dua batang kayu yang disilangkan. Di era kekaisaran Romawi dulu dua potongan kayu bersilang yang disebut salib itu lazimnya dipakai sebagai sarana hukuman bagi penjahat kelas berat. Biasanya mereka yang dituduh melawan negara atau yang dicurigai sebagai pemberontak. Karena itu penguasa Romawi menerapkan hukuman ini hanya bagi penduduk jajahan yang bukan warga Negara. Bagi orang romawi sendiri dikenakan hukuman pancung. Sebagai demikian, peristiwa penghukuman kepada si terhukum salib adalah hal yang biasa saja. ${ }^{13}$

Hal yang sama diungkapkan oleh John Stott bahwa, Orang Romawi memberlakukan penyaliban untuk para pelaku kejahatan terbesar dan memaksa mereka yang di hukum mati dengan penyaliban itu untuk memanggul salib mereka sendiri menuju tempat eksekusi. ${ }^{14}$ Selain itu, salib dikenal di Roma sebagai hukuman mati. Hal ini ditegaskan dalam buku John Stott mengatakan bahwa, salib atau penyaliban adalah suatu hukuman mati yang sangat mengerikan untuk orang Roma penyaliban adalah suatu hal yang hina; mereka mengkhususkan bagi para budak dan penjahat yang terjahat. ${ }^{15}$ Dan penyaliban juga merupakan suatu penganiayaan yang sangat sadistis karena bersifat sengaja memperlama penderitaan dan menunda kematian kadang-kadang sampai berhari-hari. ${ }^{16}$

Menurut krekristenan bahwa "The cross is a symbol o the instrument of the crucifixion of JesusChrist. ${ }^{17}$ Penyaliban Yesus merupakan pengorbanan dan penderitaan. Yesus berkorban dan menderita untuk menanggung dosa umat manusa. Dosa manusia tidak dapat diatasi dan diselesaikan dengan usaha dan perbuatan manusia. Tetapi, dosa dapat dituntaskan dan diselesaikan hanya melalui kayu salib. Pernyataan tegas dinyatakan dalam Markus 10:35, anak manusia datang bukan untuk dilayani tetapi untuk melayani untuk menjadi tebusan bagi banyak orang.

\footnotetext{
${ }^{12}$ artikelhttps://www.worldatlas.com/articles/the-history-of-the-christian-cross.html Ibid, diakses tanggal 27 Agustus 2019

${ }^{13}$ Andreas Yewangu, Salib, Memang Aneh, Akun facebook. Di akses, Tanggal 20 Agustus 2019

${ }^{14}$ Jon Stott, Kristus yang Tiada Tara, Surabaya: Momentum, 2013. Hal 17

${ }^{15}$ John R. W. Stott, Memahami Isi Alkitab, Jakarta: Persekutuan Pembaca Alkitab, 1984 hal 108

${ }^{16}$ John R. W. Stott, Memahami Isi Alkitab,hal 108

17 Artikel https://www.worldatlas.com/articles/the-history-of-the-christian-cross.html diakses tanggal 27 Agustus 2019.
} 


\section{Perspektif Perjanjian Lama Tentang Salib}

Alkitab Perjanjian Lama mengisahkan tentang peristiwa agung antara Tuhan dan umat pilhan-Nya yang mengacu kepada kasih Tuhan dan penghukuman bagi umatNya yang telah menyimpang dari jalan kebenaran-Nya yang ditandai dengan pelanggaran dan pemberontakan terhadap Allah sehingga menimbulkan hubungan manusia dengan Tuhan retak dan kehilangan kemuliaan Allah. Oleh karena itu manusia berupaya untuk membebaskan dan melepaskan diri dari dosa tersebut dengan cara yang ditempuh melalui korban keselamatan. Namun, cara tersebut menuai kehampaan dan kesia-siaan. Itu sebabnya para nabi menubuatkan tentang korban keselamatan melalui Yesus yang menderita melalui kematian di atas kayu salib. Dalam Alkitab Perjanjian Lama sangat tegas menyatakan tentang nubuat tentang peristiwa salib. There are many prophecies of the Cross in the Bible from Genesis to Revelation. From the beginning of time, God has been planning to rescue humanity from the clutches of evil by horrific death on a cross. ${ }^{18}$ Bahkan dalam hal ini Dance Kavalardo menyatakan dalam artikelnya bahwa jauh sebelum salib dikenakan pada Tuhan Yesus Kristus, Allah sendiri telah manyatakan hukuman gantung itu sebagai kutukan Allah. ${ }^{19}$ Kutukan Allah dalam hal ini mengacu kepada kemarahan Tuhan atas tindakan dan perbuatan manusia yan tercela sebab tidak menjaga kemurnian hidup yang semena-mena melakukan pelanggaran yang tidak diinginkan oleh Tuhan. namun, jika dihubungkan tentang salib maka sepatutnya bahwa manusia menerima kutukan dari Allah itu, tetapi Yesus yang menanggungnya sebab Tuhan tidak mengharapkan umat-Nya mati dalam kekekalan tetapi supaya memperoleh kehidupan yang kekal.

Walau tidak ada secara hurufiah menjelaskan tentang salib dalam Perjanjian Lama tetapi gambaran dan nubuatan tentang peristiwa salib di golgota yang dicertiakan dengan teliti.

${ }^{18}$ Artikel, https://www.crosswalk.com/special-coverage/lent/what-is-the-meaning-of-thecross.html diakses tgl 29 Agustus 2019

${ }^{19}$ Dance Kavalardo Panduwal, Sejarah Salib dalam Alkitab, artikel online, diakses tgl 21 Agustus 2019 
"Holy Abraham's near-sacrifice of his beloved son, Isaac (Gen. 22:1-19), again intimates the future sacrifice of God's only-begotten Son at Calvary but not just the passion: the Cross itself is specifically prophesied-for as Isaac was led to the hilltop for sacrifice, he carried the wood o his torment upon his back (Gen. 22:6). The image of Jesus ascending the rise to Golgotha with His Cross upon Simon's shoulders (cf. Mark 15.21; Luke 23.26) is strikingly predicted. ${ }^{20}$

Selain itu, menambahkan bahwa:

And we find in another life, that of the Patriarch Jacob, that near the point of his death, his actions, too, foreshadow the cross; for in offering the paternal blessing to Joseph's sons, the figure of his own body, with his hands laid on their heads, is of a man extended upon a cross (Gen 48.14). In the person of Israel, it is from the figure of the Cross that the divine blessing comes to the children of God. ${ }^{21}$

Oleh karena itu, walau dari keturunan dari Yakub berdasarkan dari Kejadian 48:14, namun datang dengan penuh pengorbanan dan penderitaan seperti yang dinubuatkan oleh Yesaya 53:3-7, yang menjelaskan bahwa Ia ditindas, dihukum, ditikam tetapi penyakit kitalah yang ditanggungnya. Ia ditindas dan dihina melalui penderitaan di atas kayus salib. Dari pernyataan inilah dapat kita simpulkan bahwa salib bukan salib biasa. Tetapi salib yang penuh karya terbesar dalam sepanjang sejarah dalam Alkitab.

\section{Perspektif Perjanjian Baru Tentang Salib}

Perjanjian Baru merupakan inti pelayanan Yesus dalam mewujudkan rencana Agung Tuhan untuk menyelamatkan umat-Nya yang sudah jatuh di dalam dosa yang tidak dapat dibebaskan melalui usaha dan perbuatan manusia. Upaya untuk membebaskan dan melepaskan manusia dari dosa itu hanya melalui penyaliban Yesus di kayu salib. Jika dicermati dengan seksama betapa pentingnya salib itu, maka Yesus kerap memberitakan tentang salib yang akan menimpa diri-Nya. Menurut artikel Wikipedia mengungkapkan bahwa Yesus empat kali memberitahukan penderitaan melalui penyaliban-Nya (Matius 16:21-28, Matius 17:22-23, Matius 20:17-19, Matius 26:1-2). Keempat pemberitahuan dari Yesus ini,

${ }^{20}$ Artikel Image of the Cross in the Old Testament, http://www.pravmir.com/images-of-thecross-in-the-old-testament/ diakses tgl 21 Agustus 2019

${ }^{21}$ Artikel Image of the Cross in the Old Testament, Ibid http://www.pravmir.com/imagesof-the-cross-in-the-old-testament/ diakses tgl 21 Agustus 2019 
memiliki pemakaian kata yang berbeda namun tetap tujuannya sama. Pemakaian frasa "dibunuh", "membunuh Dia", "Disalibkan", "Disalibkan". Tentang penyaliban ini merujuk pada kayu salib yang dilakukan kepada Yesus dalam Matius 27:40; Markus 15:30. Frasa “disalibkan” dalam bahasa Yunani Stauros yang artinya salib alat hukuman mati zaman itu. Ia menjadi simbol penderitaan dan kematian bagi orang Kristen. Salib Kristus adalah salah satu butir terpenting dalam iman Kristen. $^{22}$ Dalam pernyataan ini menggambarkan bahwa Perjanjian Baru menerangkan dengan tegas terkait salib yaitu lambang penderitaan dan pengorbanan yang tiada bandingnya dan deritanya yang begitu dahsyat. Rela memberikan nyawaNya untuk dijadikan tumbal dalam mewakili seluruh umat manusia yang telah dikuasai oleh dosa. Bertolak dari kerelaan diri-Nya untuk menjadi tebusan bagi umat-Nya berdasarkan dengan Yohanes 3:16, karena begitu besar kasih Allah akan dunia ini, sehingga Ia telah mengaruniakan Anak-Nya yang tunggal, supaya setiap orang yang percaya kepada-Nya tidak binasa, melainkan beroleh hidup yang kekal. Dari ayat ini menunjukkan bahwa kasih yang merupakan dorongan yang kuat untuk mengorbankan anak-Nya bagi umat manusia. Namun, sebagai titik puncak dalam mewujudkan kasih tersebut hanya melalui salib.

Dalam buku pedoman dogmatika yang ditulis oleh Dieter Becker mengatakan,

Pemberitaan Perjanjian Baru didasarkan atas kerugma-dasar dari Salib dan kebangkitan Kristus. Ini dibuktikan baik oleh lingkup dan susunan kitab-kitab Injil maupun teks-teks sentral Kisah Para Rasul (Kis.2:23 dyb.; 3:15; 4:10; 13:28 dyb.). Paulus dapat mengatakan: "Aku telah memutuskan untuk tidak mengetahui apa-apa di antara kamu selain Yesus Kristus ( I Kor. 2:2). "Tetapi aku sekali-kali tidak mau bermegah, selain dalam salib Tuhan kita Yesus Kristus" (Gal. 6:14)...Dalam Pemberitaan tentang Salib dan kebangkitan Yesus teologi dan tradisi Perjanjian Baru yang beranekaragam dan pluriform mendapat suatu titik temu. ${ }^{23}$

Oleh karena itu, patut dikatakan bahwa pemberitaan Salib dalam Perjanjian Baru sangat dominan dan mengandung pemberitaan yang penting bagi para rasul pada waktu itu, sebab salib merupakan hadiah teragung dalam sepanjang sejarah

\footnotetext{
${ }^{22}$ Hasan Susanto, Perjanjian Baru Interlinear Yunani-Indonesia dan Konkordansi Perjanjian Baru (PBIK) Jilid II, Jakarta: Lembaga Alkitab Indonesia, 2014. Hal 672

${ }^{23}$ Dr. Theol. Dieter Becker, Pedoman Dogmatika, Jakarta: BPK Gunung Mulia, 2001, hal 113
} 
umat manusia karena melalui salib umat-Nya terbuka mata rohani untuk melihat keagungan Tuhan lewat cahaya kemuliaan Allah.

\section{Refleksi Teologis: Upaya untuk Mematahkan Teologi Miring.}

Mencermati ulasan di atas dengan tegas bahwa Salib bukan hanya sekedar patung atau hiasan maupun seni lukis yang dijadikan bahan lelucon dan tertawaan bagi pemirsa yang mendengarkan ceramah kaum "pendek akal" atau "sumbu pendek" yang memiliki kebiasaan buruk menghina dan menista agama orang lain. Tetapi memiliki nilai spiritual yang begitu dalam dan begitu tinggi sebab salib adalah karya Tuhan yang sangat agung dan mulia yang merupakan hadiah yang terbesar bagi umat manusia. Itu sebabnya Paulus yang dulunya disebut Saulus sebelum bertobat termasuk golongan sumbu pendek itu yang bukan hanya mencela justru menganiaya dan membunuh kaum yang percaya kepada Tuhan. Berkat pertologan Tuhan Paulus mengalami perjumpaan dengan Tuhan sehingga bertobat sebab kepadanya diperlihatkan seorang manusia yang tersalb itu yaitu Yesus di saat perjalanan menuju Damsyik. Mulai saat itu, Paulus menjadi instrument yang sangat tangguh dan militant dalam pemberitaan Injil untuk memperkenalkan Salib itu. Sebab salib itu adalah karya terbesar Tuhan dalam sepanjang sejarah umat manusia untuk menyelamatkan manusia yang telah jatuh dalam dosa.

\section{Salib Lambang Kemenangan atas Dosa}

Dosa adalah pelanggaran dan penyimpangan serta ketidakpatutan Adam dan Hawa terhadap perintah Allah ketika ditempatkan di taman Eden. Ketidaktaatan tersebut maka Adam dan Hama jatuh di dalam dosa dan kehilangan kemuliaan Allah sehingga dosa mereka itu menjalar kepada generasi ke generasi berikutnya sampai ke seluruh umat manusia. Dalam hal ini Paulus menyatakan Roma 5:12 bahwa, Sebab itu, sama seperti dosa telah masuk ke dalam dunia oleh satu orang, dan oleh dosa itu juga maut, demikianlah maut itu telah menjalar kepada semua orang, karena semua orang telah berbuat dosa. Akibatnya, maka Paulus menegaskan bahwa, sebab upah dosa ialah maut; tetapi karunia Allah ialah hidup yang kekal dalam Kristus Yesus, Tuhan kita (Roma 6:23). Namun, Kasih Allah akan dunia ini melebihi kasih manusia sehingga Tuhan tidak rela umat ciptaan-Nya mengalami 
kematian yang kekal justru Tuhan mengharapkan umat-Nya memiliki kehidupan yang kekal. Itu sebabnya, Yesus diutus dengan berinkarnasi datang ke dalam dunia. Kehadiran Yesus ke dalam dunia menyelesaikan dan membebaskan umat manusia dari belenggu dosa. Upaya untuk membebaskan manusia dari dosa itu melalui salib. Salib menghancurkan kuasa dosa. Hal ini membuktikan bahwa tanpa salib kehidupan menjadi buram dan abu-abu bahkan hidup dalam kegelapan, namun karena salib manusia dapat menikmati kehidupan yang terang dan bercahaya di tengah-tengah dunia. Tentu, merasakan terang dan cahaya kemuliaan Allah disebabkan karena dosa manusia telah di tanggung di atas kayu oleh satu orang yaitu Yesus Kristus. Bahkan selesai dituntaskan dengan sempurna di atas kayu salib.

\section{Salib: Reconsiliasi}

Salib terbentang dua. Yang berdiri tegak disebut vertikal yang mengacu tentang hubungan manusia dengan Tuhan. sedangkan horizontal hubungan manusia dengan sesama. Namun, hubungan vertical dan horinzontal ini sudah rusak dan telah kehilangan kemuliaan Allah. Oleh karena itu, salib merupakan pusat penyelesaian yang sentral sehingga menimbulkan dampak yang eksplisit dan gamblang serta tegas. Penyelesaian yang sempurna tentang hubungan itu sejatinya bahwa manusia yang berdosa tersebut yang menanggungnya namun Yesus rela disalibkan untuk mewakilinya sehingga hubungan Tuhan dengan manusia dengan sesama kembali membaik dan harmonis sehingga tidak ada lagi jurang pemisah dan bentangan yang begitu keras untuk tidak tertembus. Pada akhirnya penyelesaian yang sempurna di atas kayu salib itu terjalin kasih yang sesungguhnya yang tercermin bahwa Tuhan mengasihi manusia, manusia mengasihi Tuhan dan begitu dengan manusia mengasihi sesamanya dengan sepenuhnya. Dampaknya adalah umat yang percaya kepada-Nya diangkat menjadi anak dan pewaris kerajaan Allah.

\section{Salib: Pengampunan}

Salib mengungkapkan nilai spritualitas yang menyentuh hati umat manusia karena seorang manusia tidak berdosa diberikan hukuman yang berat. Namun, nilai spritualitas yang menyentuh itu, dengan ungkapan yang tidak biasa dilakukan oleh 
manusia bahkan langka untuk terungkap kepada setiap manusia yang sedang mengalami penderitaan dari orang berdosa. Namun, Yesus berkata, Ampunilah mereka karena mereka tidak tahu apa yang mereka lakukan (Lukas 23:34). Pernyataan ini menjadi inspirasi bagi John Stott yang mengatakan bahwa, para Rasul menegaskan bahwa pengampunan hanya mungkin terjadi melalui melalui kematian Kristus yang menanggung dosa kita dan kelahiran baru yang memimpin orang ke dalam suatu kehidupan yang baru melalui Roh Kudus. ${ }^{24}$ Oleh karena itu, Yesus mengampuni orang yang melakukan tindakan keji yang menimpa diri-Nya dan juga mengampuni orang yang telah melakukan pelanggaran kepada Tuhan. Itu sebabnya, menjadi inspirasi bagi umat-Nya supaya saling mengampuni antara sesama. Mengampuni menjembatani jurang pemisah antara sesama. Mengampuni membongkar sakit hati yang pernah menyakiti dengan saling memaafkan.

\section{Kesimpulan}

Salib bukan salib biasa. Sebab melalui salib semua rencana Tuhan dalam dunia terwujud untuk menyelamatkan umat-Nya. Penyelamatan, reconsiliasi, pengampunan selesai dituntaskan dengan perfect di atas kayu salib. Itu sebabnya, salib bagi kaum nasrani sangat penting dan berguna sebab melalui salib itu Yesus mengorbanankan dan menderita untuk menanggung dosa umat manusia.

\section{Biodata Penulis}

Penulis sebagai Pendeta di BNKP (Banua Niha Keriso Protestan). Dosen di STT Hagiasmos Mission dan STT Pokok Anggur Jakarta. Menyelesaikan Sarjana Theologi di STT Injili Arastamar Jakarta tahun 2003 dan Pasca Sarjana dengan Magister Theologi di STT Jaffray Jakarta tahun 2016.

\section{Daftar Pustaka}

${ }^{24}$ John R. W. Stott, Memahami Isi Alkitab, Jakarta: Persekutuan Pembaca Alkitab, 1984. Hal 14 
1. Stott, John R. W. Memahami Isi Alkitab, Jakarta: Persekutuan Pembaca Alkitab, 1984

2. Becker, Dr. Theol. Dieter. Pedoman Dogmatika, Jakarta: BPK Gunung Mulia, 2001

3. Susanto, Hasan. Perjanjian Baru Interlinear Yunani-Indonesia dan Konkordansi Perjanjian Baru (PBIK) Jilid II, Jakarta: Lembaga Alkitab Indonesia, 2014

4. Stott, Jhon. Kristus yang Tiada Tara, Surabaya: Momentum, 2013

5. Tomatala, Yakob. Metodologi Riset Pendekatan Penelitian Kuantitatif dan kualitatif, Jakarta: YT Leadership Foundation, 2014

6. Subagyo, Andreas B. Pengantar Riset Kuantitatif dan Kualitatif, Bandung: Yayasan Kalam Hidup 2014

\section{Sumber Internet:}

1 Artikel Image of the Cross in the Old Testament, http://www.pravmir.com/images-of-the-cross-in-the-old-testament/ diakses tgl 21 Agustus 2019

2 Artikel Image of the Cross in the Old Testament, Ibid http://www.pravmir.com/images-of-the-cross-in-the-old-testament/ diakses tgl 21 Agustus 2019

3 Artikel, https://www.crosswalk.com/special-coverage/lent/what-is-themeaning-of-the-cross.html diakses tgl 29 Agustus 2019

4 Dance Kavalardo Panduwal, Sejarah Salib dalam Alkitab, artikel online, diakses tgl 21 Agustus 2019

5 Andreas Yewangu, Salib, Memang Aneh, Akun facebook. Di akses, Tanggal 20 Agustus 2019

6 Artikel https://www.worldatlas.com/articles/the-history-of-the-christiancross.html diakses tanggal 27 Agustus 2019.

7 artikelhttps://www.worldatlas.com/articles/the-history-of-the-christiancross.html diakses tanggal 27 Agustus 2019

8 artikelhttps://www.worldatlas.com/articles/the-history-of-the-christiancross.html Ibid, diakses tanggal 27 Agustus 2019 
9 artikelhttps://www.worldatlas.com/articles/the-history-of-the-christiancross.html Ibid, diakses tanggal 27 Agustus 2019

10 https://indoprogress.com/2019/08/salib-jin-kafir-dan-papua/ Ibid, tanggal 20 Agustus 2019

11 Artikel ini dikuip tanggal 20 Agustus 2019 di https://jogja.suara.com/read/2019/04/06/221120/nisan-salib-di-yogyakartadibakar-terduga-pelaku-sempat-tidur-di-makam

12 https://nasional.tempo.co/read/1157220/pemotongan-tanda-salib-dianggapindikasikan-pelemahan-toleransi/full\&view=ok diakses Tanggal 20 Agustus 2019

13 Artikel di kutip tanggal 20 Agustus 2019 di https://indoprogress.com/2019/08/salib-jin-kafir-dan-papua/

14 Artikel yang dikutip tanggal 20 Agustus 2019 di https://www.worldatlas.com/articles/the-history-of-the-christian-cross.html 